técnicos industriais enquanto cursam a faculdade, ou, mais genericamente, que sua formação escolar pré-universitária não os esteja auxiliando de qualquer forma a sobreviver na condição de universitários, com alguma vantagem sobre os que se formaram no ensino tradicional. Se isso estiver ocorrendo, e dado que a clientela do ensino técnico, principalmente 0 industrial, provém das assim chamadas camadas sociais de baixa renda, é de convir que a nova política educacional se constitua de abertura e não de restrição de oportunidades.

Excetuadas as observações, é de se ressaltar ser a obra uma séria e bem organizada exploração da constituição, evolução e transformações do ensino técnico no Brasil.

José Carlos Garcia Durand
Grã-Bretanha e o início da modernização no Brasil 1850-1914

Por Richard Graham. São Paulo, Editora Brasiliense, 1973.

Cinco anos depois de publicado em inglês, finalmente aparece em português 0 importante trabalho de Graham.

O livro é uma continuação da obra de Alan K. Manchester, British preeminence in Brazil, que examina as relações entre Inglaterra e Brasil na primeira metade do século $X I X$.

- O trabalho de Graham contém uma tentativa de interpretação do papel desempenhado pela Inglaterra nas transformaçōes socioeconômicas ocorridas no Brasil a partir de 1850. Segundo Graham, a Inglaterra foi a grande responsável pela promoção dos primeiros passos brasileiros para uma sociedade moderna.

A tese desenvolvida por Graham inspirou-se, evidentemente, nas teorias da modernização em voga nos Estados Unidos, na década de 1960. Nesse sentido, logicamente ela é equivocada. Entretanto nem por isso o livro perde a sua importância, pois contém informações preciosíssimas para qualquer estudioso do período.

0 equivoco de Graham está na suposição de que a ideologia liberal inglesa tenha orientado as ações daquela nação de forma a promover a modernização socioeconômica do Brasil quando é evidente que a orientação das ações inglesas dependiam fundamentalmente do estágio de desenvolvimento capitalista naquela sociedade.

Graham argumenta, por exemplo, que o investimento em ferrovias, especialmente na região cafeeira, tinha uma intenção modernizante além de servir de instrumento eficiente para o desenvolvimento da economia agroexportadora. Entretanto, torna-se difícil perceber a existência dessa intenção, quando se sabe que os ingleses não expandiram a Santos-Jundaí até Campinas porque sabiam que os lucros maiores advinham do controle do tronco ferroviário que ligava São Paulo a Santos. Em outras palavras, a construção da Santos-Jundial ou da São Paulo Railway Co. Ltd. foi feita tendo em vista somente um cálculo de lucro e não intenções modernizantes, pois, do contrário, os ingleses teriam ampliado a sua linha até Campinas. Não o fizeram exclusivamente porque os lucros seriam menores e eles já possuíam o controle do transporte do café entre São Paulo e Santos o que, do ponto de vista econômico, era realmente o espaço estratégico.

Graham supõe também que a política inglesa em relação à escravidão brasileira tenha sido determinada em grande parte pela ideologia liberal então reinante naquele pais. Se isso fosse verdade, seria de se esperar que a política inglesa em relação a qualquer regime escravocrata 
fosse idêntica à praticada com relação ao Brasil. Entretanto, parece que isso não ocorreu. Assim, durante a guerra civil norte-americana, se a Inglaterra não ajudou o Sul, manteve-se numa posição de estrita neutralidade que, evidentemente, contrariava princlpios da ideologia liberal.

Finalmente, o próprio Graham em trabalhos posteriores demonstra como o liberalismo econômico foi um instrumento da expansão capitalista inglesa que incorporou o Brasil durante a segunda metade do. século XIX e até cerca de 1914.

A tese equivocada, entretanto, não diminui a importância do trabalho de Graham, que contém inúmeras informações de fundamental importância para o estudioso do período. Assim, as páginas sobre o desenvolvimento ferroviário no Brasil, o comércio de importação-exportação e os investimentos ingleses na infra-estrutura urbana brasileira fornecem subsidios dificeis de serem encontrados. 0 trabalho de pesquisa realizado pelo autor é extremamente bem feito e demonstra a sua competência técnica e o seu grande conhecimento das fontes brasileiras.

Manoel Tosta Berlinck

\section{História e desenvolvimento}

A contribuição da historiografia para a teoria e prática do desenvolvimento brasileiro.

Por Caio Prado Jr., São Paulo, Editora Brasiliense, 1972. 92 p.

Com que perspectiva nos acena a atual política econômica? Como se apresenta, como se comporta e para onde aponta o "modelo" que se escolheu como baliza de nosso desenvolvimento? Estas indagações precedidas de diagnósticos pouco otimistas, quando analisadas à luz da his. tória, lastreiam a tese de Caio Prado Jr., que, entre 1971 e 1972 , revisou-a e atualizou-a para constituir o presente livro, na expectativa de que o mesmo desse uma abertura de perspectiva $e$ incitasse historiadores $e$ economistas a retomarem 0 assunto.

A sua tarefa essencial neste trabalho ocupa-se da proposição da abordagem historiográfica nos estudos que ora se voltam ao crescimento econômico e desenvolvimento nacionais, por constituirem tema essencialmente históricos. Dirige-se ao historiador brasileiro "que lida com dados essenciais e impres* cindiveis para o conhecimento e interpretação do presente", para que ele faça voltar a sua atenção àquelas circunstâncias históricas passadas que se manifestam nas que ora vivemos. Tem a história como fonte informativa e explicativa do processo de desenvolvimento do nosso Pais, o que lhe permite compreender a especificidade de nossa formação e a partir daí estabelecer as premissas para uma política econô. mica que nos seja realmente adequada.

Aos economistas ortodoxos, principalmente àqueles por meio dos quais se exprime e se realiza a nossa política econômica, o autor pretende mostrar que "a análise econômica como decorrência de sua própria natureza e estilo de trabalho, e privada de uma suficiente perspectiva histórica irá ocupar-se do assunto com seus métodos específicos e exclusivos, e por isso, altamente insuficientes para a abordagem e consideração dele em seu conjunto e totalidade".

Isto significa que o tratamento a partir de "modelos teóricos" coloca os fatos de forma sim. plificada e esquemática $e$, nessa medida, distorcidos. Ao conside. rarem apenas os fenômenos possiveis de mensuração, trabalha. dos num esquema de variáveis, limitam-se a conceituar desen. volvimento em termos de cres. cimento econômico.

0 autor diz que esses modelos seriam válidos se servissem de hipóteses de trabalho, sendo modificados conforme o decorrer da pesquisa, levando em con. ta a especificidade dos fatos históricos concretos; mas ocorre justamente o contrário: são for. mulados em definitivo a priori, para orientação da pesquisa e são os acontecimentos históricos que entram como "encaixe" no 